SLABKo $V$. N., ZaPOLSKA YU. A. Formation of professional foreign language competence of engineering and technical students in the context of digitalization of higher professional education.

Research topicality. Modern conditions of digitalization of education provide for a need to reconsider the purpose, content and technology of foreign language teaching, development of multilevel personality-oriented foreign language training of students using information and communication technologies and establishment of active information and educational language environment in higher educational institutions.

Problem statement. The scientific and pedagogical problem - development of professional foreign language competence of engineering and technical students as the ability for business and interpersonal interaction in the multicultural environment is outlined.

Review of recent research and publications. Theoretical and practical aspects of the development of professional foreign language competence of students were studied by M. Vinnyk, L. Hrishko, V. Osadchyi, T. Hutchinson. Theoretical issues of communication were studied by M. Kahan, S. Spencer, K. Finch,in particular in the field of information technology - S. Johnson and L. Rosencrance. However, no scholars closely studied the analysis of the problem of development of professional and foreign language competence of future engineers in the conditions of digitalization.

Setting objectives. The study is intended to analyse the problem of the development of professional and foreign language competence of future engineers using information and communication technologies in the context of digitalizationof higher education.

Results. Digitalization of education is considered as a process of providing the field of education with methodology, technology and practice of development and optimal use of modern information and communication technologies focused on the realization of psychological and pedagogical learning goals. Therefore, the article identifies the possibilities of using information and communication technologies in the process of developing professional and foreign language competence of engineering students. The need of using information and communication technologies in specialized foreign language classes and in the cycle of professional subjects, in the process of preparing term and final qualification papers, preparing for participation in conferences and international projects is substantiated.

Conclusions. Effective formation of professional and foreign language competence of engineering and technical students is ensured by the use of information and communication technologies. Specialized foreign language competence allows solving communicative objectives in the field of professional activity, carrying out foreign language communication with native speakers of a foreign language and performing search and analysis of information necessary for future activity.

Keywords: professional foreign language competence, engineering and technical students, information and communication technologies, digitalizationof higher professional education.

DOI: https://doi.org/10.31392/NZ-npu-144.2019.21

УДК $378: 14$

Сливка Б. С.

\title{
ФОРМУВАННЯ ХРИСТИЯНСЬКОЇ МОРАЛІ ДОШКІЛЬНИКІВ НАПРИКІНЦІ XX - НА ПОЧАТКУ XXI СТОЛІТТЯ: УЗАГАЛЬНЕННЯ МОЖЛИВОСТЕЙ ВИКОРИСТАННЯ ІСТОРИЧНОГО ДОСВІДУ
}

Обгрунтовано концептуальні підходи до формування християнської моралі дошкільників у період незалежності украӥнської держави. Визначено основні детермінанти пастирської роботи з дітьми дошкільного віку (антропологія пастирства, пастирська психологія, пастирська педагогіка, дошкільна освіта, дошкільне виховання, сімейно-родинна освіта, сімейно-родинне виховання, иерковний спів тошо). Виокремлено чинники впливу на розвиток формування християнської моралі доикільників (ідеологічні, 
філософсько-культурні, науково-педагогічні, богословські, сочіально-економічні, освітньо-навчальні, організаційно-методичні та інформаційно-технологічні). Запропоновано періодизаціюо розвитку християнської моралі дошкільників у пастирській педагогічі кіния XX - початку ХХІ століття (19911999 рр. - становлення начіональної дошкільної освіти, створення концепиї та базового компоненту дошкільного виховання й Національної програми “Діти Украӥни” з урахуванням відродження релігійного виховання на тлі минулих заборон радянського періоду; 2001-2009 рр. - формування законодавчої бази дошкільної освіти, розроблення нових варіантів програм виховання і навчання дітей у дошкільні роки та створення базової програми розвитку дитини “Я у Світі” з офіиійним входженням християнського виховання та спрямуванням на розвиток християнської моралі дошкільників; 2010-2013 рр. - розвиток дошкільного виховання як самостійної галузі украӥнської педагогіки на засадах християнства на основі нової редакції Базового компонента дошкільної освіти в Україні та оновленої програми виховання $i$ навчання дітей від 3 до 7 років “Дитина”; 2014-2017 рр. - розвиток християнської моралі з урахуванням значних соціальних зрушень у контексті нової редакції програми “Я у світі” та проекту Конщепції розвитку освіти України на період 2015-2025 рр.). Виявлено тендениії розвитку християнської моралі дошкільників засобами пастирської діяльності в Україні (залучення до сімейного морального виховання священнослужсителів, залучення пасторів до морального виховання доикільників, побудова виховного процесу на національних изіностях, посилення релігійної спрямованості виховання дошкільників, інтеграчіі світських та релігійних виховних впливів у формуванні моралі дошкільника тощо). Запропоновано конкретні методики формування християнської моралі дошкільників як узагальнення можливостей використання історичного досвіду досліджуваного періоду.

Ключові слова: християнська мораль, дошкільники, історичний досвід, пастирська діяльність, кінець ХX-початок ХХІ століття.

Культурно-історичні обставини кінця XX - початку XXI ст. визначаються чинниками, під впливом яких відбувається моральне виховання молоді. На думку низки вчених, такими чинниками є глобалізаційні процеси у світовому суспільнополітичному та культурному просторі, інформатизація, технологізація, значення у повсякденному житті матеріального чинника, що загалом поглиблює моральний аспект особистого і суспільного життя. Тому "сучасне моральне виховання має відіграти випереджальну роль у викликах демократичному процесу, базуватися на кращих здобутках національної культури і педагогіки, сприяти припиненню соціальної деградації, стимулювати самоорганізацію та особисту відповідальність людей" [8, с. 523].

Суперечливі процеси наприкінці XX - на початку XXI століття, зокрема "нестабільність політичного й соціально-економічного становища, кризові явища, зміна ціннісних орієнтацій серед молоді, послаблення ролі школи та сім"ї у формуванні особистості" [7, с. 3] вимагають змін у вихованні молодого покоління, необхідності пошуків нових, ефективніших фоом і методів навчання і виховання, ефективних шляхів розвитку особистості. У бутті сучасної людини, особливо у великих містах, предметний, рукотворний світ домінує над природним, внутрішнім життям, навіть над спілкуванням з людьми, що їі оточують. Переважають усілякі прилади, машини, одяг, прикраси, хімічні препарати, які важливі для комфорту, проте заміна життєвого світу людини речами порушує природну гармонію, засвідчує небезпечні тенденції.

У вітчизняному науково-педагогічному дискурсі (В. Андрущенко, І. Бех, О. Вишневський, В. Скотний, Н. Скотна та ін.) розглянуто ідеї морального виховання в релігійній педагогіці. Проблемам морально-релігійного виховання особистості присвячені праці таких науковців, як М. Євтух, О. Каневська, О. Ярмоленко. Розвиток дітей раннього віку розглядають вітчизняні дослідники 
Л. Артемова, А. Богуш, Г. Белєнька, О. Богініч, Н. Гавриш, І. Дичківська, О. Доронова, О.Кононко, Н. Лисенко, Т. Поніманська, І. Рогальська, Т. Степанова, Г. Сухорукова.

Водночас можливості пастирської діяльності для фрормування християнської моралі дошкільнят в історико-педагогічному аспекті не були предметом спеціального дослідження.

Завдання нашого дослідження - аналіз та обґрунтування концептуальних підходів до фрормування християнської моралі дошкільників у період незалежності української держави.

Ідеї морального виховання у культурно-історичних обставинах кінця XX початку XXI ст. передбачають реалізацію моральних цінностей, що відкладаються в свідомості дитини у вигляді норм, принципів, ідеалів, понять тощо. Це завдання реалізується у поєднанні досвіду світського та релігійного виховання. Критерієм ефективності морального виховання $\epsilon$ моральність, яка проявляється у його повсякденній поведінці у формі вчинків, переконань, нахилів, почуттів, звичок, стійких моральних якостей, доброчесності тощо.

Демократичні процеси, які розпочалися в умовах розбудови незалежної української державності, істотно вплинули на відродження релігійного життя, як і зворотний вплив на політичний процес. Ідеологічний плюралізм, що змінив тоталітарну антирелігійну ідеологію, започаткував у свідомості українського народу нове ставлення до релігії, яка в нових умовах стала наповнюватися національним змістом [5].

Для пастиря важливо враховувати також суспільні й державні процеси в конкретний час, що розширюе пастирські повноваження й піклування, пристосовує до певних умов. Позабогослужбова діяльність українського православного пастиря на початку XXI ст. починається щонайменше зі згуртування нації, формування державності і реального об'єднання всіх церков України. Це значно розширює повноваження сучасного православного пастиря в Україні під час роботи з молоддю, хворими, військовими, ув'язненими, мітингарями з окупованих територій, переселенцями, людьми в окупації, особами в зоні воєнних дій, патріотично налаштованими депутатами тощо.

Останніми роками часто спостерігаємо неправомірне у масовій свідомості ототожнення понять “духовний розвиток" і “релігійне виховання", хоча виховання на релігійних засадах (заповідях, традиціях) $€$ водночас і складовою фрормування духовної культури, і засобом цієї діяльності [2, с. 6-8].

На нашу думку, християнському вихованню мають передувати елементарне пізнання дитиною світу, навколишнього середовища, усвідомлення свого “Я”. У підсвідомості повинні бути закладені добрі почуття, тепло і ласка, щоб не допустити формального засвоєння азів релігійних понять і догм. Роль пастиря полягає в умінні так донести проповідь (хоча б дистанційно, через близьких дорослих людей), щоб дитина не зазнала духовного, світоглядного каліцтва. Адже духовне каліцтво має негативні наслідки у релігійному вихованні. Засвоєння релігійних норм дитиною, яка 
виросла у бездуховній, аморальній сім'ї, або не відбудеться, або буде мати не тільки прогалини, а й викривлені, поверхові знання, срямовані на здобуття в будь-який спосіб матеріальних благ, матеріальних засобів існування.

На наше переконання, основними детермінантами (визначниками) пастирської роботи з дітьми дошкільного віку $\epsilon:$ антропологія пастирства, пастирська психологія, пастирська педагогіка, дошкільна освіта, дошкільне виховання, сімейно-родинна освіта, сімейно-родинне виховання, церковний спів, координаторська діяльність пресвітера, історія Української православної церкви, ставлення до природи, рослин, тварин, дітей, дорослих тощо. Це значно розширює повноваження сучасного православного пастиря в Україні, i стосується це роботи з молоддю, хворими, військовими, ув'язненими, мітингарями з окупованих територій, переселенцями, людьми в окупації, особами в зоні воєнних дій тощо. Наше завдання полягає в науковому обґрунтуванні пастирської діяльності з дошкільнятами у процесі формування у них християнської моралі.

Розробляючи періодизацію розвитку християнської моралі дошкільників у пастирській педагогіці кінця XX - початку XXI століття, ми намагались урахувати особливості як освітнього, так і релігійного розвитку українського суспільства в означений період.

До основних віх у розвитку дошкільної освіти доцільно віднести зокрема такі: 1991 р. - Закон “Про освіту", 1993 р. - Державна національна програма "Освіта" (Україна XXI століття), 1993 р. - Концепція дошкільного виховання, 1994 р. - Концепція національного виховання, 1996 р. Національна програма “Діти України”, 1999 р. - Базовий компонент дошкільної освіти, 2001 р. - Закон "Про дошкільну освіту", 2003 р. “Положення про дошкільний навчальний заклад”, 2003 р. - новий варіант програми виховання і навчання дітей від 3 до 7 років “Дитина”, 2004 р. програма "Дитина в дошкільні роки”, 2008 р. - Базова програма розвитку дитини “Я у Світі", 2010 р. - І Всеукраїнський з'їзд педагогічних працівників дошкільної освіти, 2010 р. - Закон України "Про внесення змін до законодавчих актів з питань загальної середньої та дошкільної освіти", 2010 р. - інструктивно-методичний лист МОН України "Про організацію роботи 3 дітьми 5-річного віку”, 2011 р. - програма “Дитина в дошкільні роки", 2012 р. - нова редакція Базового компонента дошкільної освіти в Україні, 2012 р. - оновлена програма виховання і навчання дітей від 3 до 7 років “Дитина”, 2014 р. - нова редакція програми “Я у світі”, 2015 р. - проект Концепції розвитку освіти України на період 2015-2025 рр.

Відповідно, основними віхами розвитку релігійного життя в означений період були такі: 1992-2004 - проросійський курс, співпраця із проросійським спектром українського політикуму; 2007-2013 - повернення до україноцентризму і боротьба за самостійність УПЦ після того, як 2007 року відбувся Архієрейський собор УПЦ, на якому було засуджене проросійське “політичне православ'я”, взятий курс на деполітизацію 
церковного життя і становлення УПЦ як де-фракто автокефральної церкви; 2014-2016 - виникнення і розвиток системної кризи Української православної церкви, що проявлялось у тому, що залишки авторитету УПЦ в релігійному середовищі України та суспільстві були знищені завдяки наявній із РФ інформаційній політиці УПЦ, яка повернулася до "мови ненависті" і риторики "оточеної фортеці".

Це дало змогу виокремити чинники впливу на розвиток формування християнської моралі дошкільників, а саме: ідеологічні; фрілософсько-культурні; науково-педагогічні; богословські; соціальноекономічні; освітньо-навчальні; організаційно-методичні; інфрормаційнотехнологічні

Отже, пропонуємо таку періодизацію розвитку християнської моралі дошкільників у пастирській педагогіці кінця $X X-$ початку XXI століття:

I. 1991-1999 pp. - становлення національної дошкільної освіти, створення концепції та базового компоненту дошкільного виховання й Національної програми "Діти України" $з$ урахуванням відродження релігійного виховання на тлі минулих заборон радянського періоду.

II. 2001-2009 pp. - фрормування законодавчої бази дошкільної освіти, розроблення нових варіантів програм виховання і навчання дітей у дошкільні роки та створення базової програми розвитку дитини “Я у Світі" 3 офіційним входженням християнського виховання та спрямуванням на розвиток християнської моралі дошкільників.

III. 2010-2013 pp. - розвиток дошкільного виховання як самостійної галузі української педагогіки на засадах християнства на основі нової редакції Базового компонента дошкільної освіти в Україні та оновленої програми виховання і навчання дітей від 3 до 7 років "Дитина".

IV. 2014-2017 pp. - розвиток християнської моралі з урахуванням значних соціальних зрушень у контексті нової редакції програми "Я у світі" та проекту Концепції розвитку освіти України на період 2015-2025 pp.

Сьогодення змушує вирішувати складні і незвичні проблеми, що посилює важливість фрормування особистості починаючи з дитинства, свідомого ставлення до життя, умінь виділяти, кваліфікувати, запам'ятовувати та збагачувати власний досвід новою інформацією. Тому життєва установка "бути" змінюється іншою - здаватися таким. Це "надзвичайно тривожна тенденція, яка засвідчує нездоров'я нації. Отже, кожний з нас як особистість, громадянин, педагог зобов'язаний визнати цей фракт, визначити причини такого стану речей, переглянути пріоритети дошкільної освіти, використовувати ефективні освітні технології. Тому пріоритетом для освітян-дошкільників має стати розвиток особистості, її компетентності у різних сорерах життя, а не ії предметна підготовка до майбутнього шкільного життя" [3, с. 5]. Лише за таких умов дитина навчиться з перших років іти назустріч життю, реалізовувати свій потенціал, 
бути відкритою для життєвих вражень, жити у злагоді з довкіллям і у згоді зі собою.

Духовно-моральне виховання дитини передбачає фрормування і розвиток таких складових, як: загальнолюдські цінності - набуті попереднім поколінням морально-духовні надбання, що є основою поведінки і життєдіяльності окремої людини та суспільства загалом; національні цінності - історично зумовлені і створені народом погляди, ідеали, традиції, звичаї, обряди, які ґрунтуються на загальнолюдських цінностях, але відрізняються національними проявами і $€$ основою соціальної діяльності людей певної етнічної групи; громадянські цінності - цінності, які проявляються у почутті власної гідності, внутрішньої свободи, дисциплінованості, повазі до інших, у гармонійному поєднанні патріотичних, національних та міжнаціональних почуттів; сімейні цінності основні цінності у стосунках у сім'ї, що проявляються в шанобливому ставленні до членів родини, до старших, у пам'яті про предків, у піклуванні про сім'ю [4, С. 107-111].

В означуваний період виявлено такі тенденції розвитку християнської моралі дошкільників засобами пастирської діяльності в Україні: аксіологізація змісту навчання та виховання дошкільників; зняття заборон радянського періоду на релігійне виховання; переорієнтація 3 атеїстичного на християнський світогляд; посилення уваги до християнської педагогіки та пастирології; залучення до сімейного морального виховання священнослужителів; залучення пасторів до морального виховання дошкільників; побудова виховного процесу на національних цінностях; посилення релігійної спрямованості виховання дошкільників; інтеграція світських та релігійних виховних впливів у формуванні моралі дошкільника; концептуалізація; мультикультурність; оновлення форм, методів та засобів роботи з дошкільниками за рахунок розвитку інформаційно-комунікативних технологій; періодичне зниження батьківської опіки дошкільників внаслідок надмірного перевантаження; підвищення кваліфікації підготовки пастирів та розширення мережі релігійних навчальних закладів; піднесення національного та релігійного рівня в умовах війни; прогностичність.

Узагальнення досвіду використання фрорми і методів пастирського богослов'я у формуванні християнської моралі дошкільників.

Пастирська опіка дітей дошкільного віку має здійснюватися згідно 3 перевіреними практикою правилами й процедурами, які визначають методику (годеґетику) необхідних навчально-виховних процесів. До змісту методики входить низка педагогічних понять: метод, підхід, прийом, засіб, технологія тощо, які реалізовуються у відповідних формах. Основними педагогічними поняттями методики $є$ фрорма і метод.

Методика пастирської роботи з дітьми дошкільного віку, яка задає межі формування дитиною власної сутності через пастирську допомогу у діалозі з Вищою Сутністю. Потрібно знайти такі підходи до дошкільника, щоб він зрозумів, як йому організувати своє майбутнє житт згідно з Божим задумом, у межах дії Божих законів. Тобто пастир повинен вибрати таку 
конкретну методологію, яка пов'язана з культурою і методикою мислення дитини. Якщо природно організувати мислення, то правильна, онтологічна поведінка буде й у майбутньому, будуть вироблені такі богословські пізнавальні установки, які б інтегрувалися у повсякденний досвід людських індивідів. У повсякденному житті дорослої віруючої людини мають функціонувати конкретні методологічні установки, закладені пастирем ще у дошкільному віці.

Дихотомія - це ефективний вид поділу. Вона характерна тим, що члени поділу не перетинаються (тобто виключають одне одного), такий поділ здійснюється тільки за одною основою, а також дотримується правило співрозмовності. Операцію поділу застосовують у випадках, коли необхідно визначити види родового поняття. Прикладом дихотомічного поділу може слугувати поділ злочинів на навмисні і ненавмисні [1].

У дихотомії “дитина-Бог” - основа поділу і, відповідно, видоутворювальна ознака - об’єкт, на який скероване діяння - успадкування Царства Небесного. Звідси випливає два суперечливих (які не мають перетину) один одному поняття: добро і зло. У поняття "зло" входять різноманітні види і, таким чином, два утворених дихотомією поняття вичерпують весь об'єкт діленого поняття, тому розглядуваний об'єкт - успадкування Царства Небесного відображається в одному з них (добро або зло). При творенні добра умовні двері до Царства Небесного відкриті, а при творенні зла - замкнені.

Медіатор-пастир повинен скеровувати праведних батьків до того, щоб дитина зрозуміла, що Бог перебуває в глибині її істоти, що Він близький, і можна реально вести свою дитину до святості, оскільки діти є Божими спадкоємцями щасливого життя. Тонкощі провадження дитини до Бога містяться у молитвах, частому перебуванні на богослужіннях у храмі, що $\epsilon$ надійним захистом на все життя.

Медіатор дихотомії “дитина-Бог” своїм обов'язком вважає теоретичну підготовку до сповіді. Передусім це стосується акцентування уваги на тому, що сповідь - це християнська перевірка готовності дитини на примирення з Богом через здійснені гріховні помилки, нечисті наміри, приховування своїх неправильних дій і думок через сором. Це своєрідний іспит на духовну зрілість, який потрібно складати протягом усього життя із знанням, що говорити на сповіді, щоб стати справді вільною людиною. Для сповідника потрібен постійний духовний керівник-медіатор, який дає потрібні рекомендації навіть у разі забуття гріхів, які й потрібно визнати на наступній сповіді.

Медіатор повинен навчити дитину приймати власні постанови щодо майбутнього виправлення. Йдеться не про вимушене покаяння, що фальшивою присягою здійснювалося би здебільшого на догоду іншим, а про вміння прислухатися до голосу совісті.

Основні принципи медіації - добровільність, самовизначення, неформальність, гнучкість, відповідальність та незалежність медіатора [6]

Звичайно, медіаційна діяльність немислима без принципу незалежності. Незалежність медіатора полягає в неналагодженні примітивних корупційних 
зв'язків. Це стосується не жадання матеріальних, фінансових вигод, різноманітної допомоги від третіх осіб. Основне у незалежності - це постійне збагачення духовної скарбниці дошкільника.

Медіації дихотомії “дитина-Бог” здійснюються і на такому етапі як процедура медіації бездоглядних дітей. У цій ситуації перебувають дорослі 3 дітьми, які живуть на вулиці, в тимчасових гуртожитках, незаконно зайнятих житлових приміщеннях (часто без належних побутових і санітарних умов) або тимчасовому приміщенні без постійного права володіння.

Отже, медіатор дихотомії “дитина-Бог" покликаний усіляко сприяти постійному перебуванню дитини в присутності Бога.

Висновки. Визначено основні детермінанти пастирської роботи з дітьми дошкільного віку (антропологія пастирства, пастирська психологія, пастирська педагогіка, дошкільна освіта, дошкільне виховання, сімейно-родинна освіта, сімейно-родинне виховання, церковний спів тощо). Виокремлено чинники впливу на розвиток формування християнської моралі дошкільників (ідеологічні, фрілософсько-культурні, науково-педагогічні, богословські, соціально-економічні, освітньо-навчальні, організаційно-методичні та інформаційно-технологічні). Запропоновано періодизацію розвитку християнської моралі дошкільників у пастирській педагогіці кінця XX - початку XXI століття. Виявлено тенденції розвитку християнської моралі дошкільників засобами пастирської діяльності в Україні (зняття заборон радянського періоду на релігійне виховання, переорієнтація з атеїстичного та християнський світогляд, посилення уваги до християнської педагогіки та пастирології, залучення до сімейного морального виховання священнослужителів, залучення пасторів до морального виховання дошкільників, побудова виховного процесу на національних цінностях, посилення релігійної спрямованості виховання дошкільників, інтеграції світських та релігійних виховних впливів у формуванні моралі дошкільника тощо). Запропоновано конкретні методики формування християнської моралі дошкільників як узагальнення можливостей використання історичного досвіду досліджуваного періоду.

\section{Використана література:}

1. Дихотомія. URL : http://www.e-reading.club/chapter.php.

2. Долинна О., Низковська О. Розвивати духовний потенціал особистості дошкільника. Дошкільне виховання. 2013. № 9. С. 6-8. URL: http://www.e-catalog. name/x/kram/ kram?LNG=\&Z21 ID=\&I21 DBN.

3. Кононко О. Л., Луценко В. О., Нечай С. П. та ін. Формуємо у старших дошкільників цілісне світобачення: навч.-метод. посібник. Київ : Імекс-ЛТД. 260 с. С. 5.

4. Панченко В. О. Організація духовно-морального виховання дітей у дошкільних закладах [Текст]. Науковий вісник Миколаївського державного університету імені В. О. Сухомлинського: педагогічні науки. 2014. Вип. 1.45. С. 107-111.

5. Пасічний Р. Я. Формування соціально-політичної доктрини Української греко-католицької церкви [Текст]: автореф. дис. ... канд. політ. наук. Львів, 2016. 19 с.

6. Принципи медіаціï. URL: http://pidruchniki.com/164001 1663595/pravo/printsipi_mediatsiyi.

7. Черкасов В. В. Розвиток музично-педагогічної освіти в Україні (друга половина XX - початок XXI століття) : автореф. дис. ... докт. пед. наук. Київ, 2009. - 38 с. С. 3. 
8. Чорна К. І. Моральне виховання. Енциклопедія освіти / Акад. пед. наук України ; гол. ред. В.Г. Кремень. Київ : Юрінком Інтер, 2008. 1040 с. С. 523-524.

\section{References:}

[1] Dykhotomiia. URL : http://www.e-reading.club/chapter.php.

[2] Dolynna O., Nyzkovska O. (2013). Rozvyvaty dukhovnyi potentsial osobystosti doshkilnyka. Doshkilne vykhovannia. № 9. S. 6-8. URL: http://www.e-catalog. name/x/kram/ kram?LNG=\&Z21 ID=\&I21 DBN.

[3] Kononko O. L., Lutsenko V. O., Nechai S. P. ta in. Formuiemo u starshykh doshkilnykiv tsilisne svitobachennia: navch.-metod. posibnyk. Kyiv : Imeks-LTD. 260 s. S. 5.

[4] Panchenko V. O. (2014). Orhanizatsiia dukhovno-moralnoho vykhovannia ditei u doshkilnykh zakladakh [Tekst]. Naukovyi visnyk Mykolaivskoho derzhavnoho universytetu imeni V. O. Sukhomlynskoho: pedahohichni nauky. Vyp. 1.45. S. 107-111.

[5] Pasichnyi R. Ya. (2016). Formuvannia sotsialno-politychnoi doktryny Ukrainskoi hreko-katolytskoi tserkvy [Tekst]: avtoref. ... dys. kand. polit. nauk. Lviv. 19 s.

[6] Pryntsypy mediatsii. URL: http://pidruchniki.com/1640011663595/pravo/printsipi_mediatsiyi.

[7] Cherkasov V. V. (2009). Rozvytok muzychno-pedahohichnoi osvity v Ukraini (druha polovyna KhKh pochatok KhKhI stolittia): avtoref. dys. ... dokt. ped. nauk. Kyiv. 38 s. S. 3.

[8] Chorna K. I. (2008). Moralne vykhovannia. Entsyklopediia osvity / Akad. ped. nauk Ukrainy; hol. red. V. H. Kremen. Kyiv : Yurinkom Inter. 1040 s. S. 523-524.

Сливка Б. С. Формирование христианской морали дошкольников в конце XX - в начале XXI века : обобщение возможнностей использование исторического опыта.

Обоснованы конщептуальные подходы до формирования христианской морали дошкольников в период независимости украинского государства. Определены основные детерминанты пастьрской работь с детьли дошкольного возраста (антропология пастырства, пастьрская психология, пастырская педагогика, доикольное образование, доикольное воспитание, семейно-семейное образование, семейно-семейное воспитание, иерковное пение и тому подобное). Выделены факторы влияния на развитие формирования христианской морали дошкольников (идеологические, философско-культурные, научно-педагогические, богословские, сочиально-экономические, образовательно-учебные, организачионнометодические и информаиионно-технологические). Предложена периодизаиия развития христианской морали дошкольников в пастырской педагогике кониа ХХ - начале ХХІ века (1991-1999 г2. - становления национального дошкольного образования, создания конщепиии и базовые компоненту дошкольного воспитания и Начиональной программы “Деть Украины” с учетом возрождения религиозного воспитания на фоне прошльх запретов советского периода; 2001-2009гг. - формирования законодательной базы доикольного образования, разрабатыввания новых вариантов программ воспитания и учебы детей в дошкольные годы и создание базовой программы развития ребенка "Я в Мире” с официальным вхождением христианского воспитания и устремлением на развитие христианской морали дошкольников; 2010-2013г2. - развитие дошкольного воспитания как самостоятельной отрасли украинской педагогики на принципах христианства на основе новой редакиии Базового компонента дошкольного образования в Украине и обновленной программы воспитания и учебы детей от 3 до 7 лет "Ребенок"; 2014-2017 г2. - развитие христианской морали с учетом значительных сочиальных сдвигов в контексте новой редакиии программь "Я в мире" и проекта Концепџии развития образования Украины на период 2015-2025 г2.). Выяявлены тенденщии развития христианской морали дошкольников средствами пастырской деятельности в Украине (привлечение к семейному моральному воспитанию священнослужителей, привлечения пасторов к моральному воспитанию дошкольников, построение воспитательного процесса на национальных ценностях, усиление религиозной направленности воспитания доикольников, интеграиии светских и религиозных воспитательных влияний в формировании морали дошкольника и тому подобное). Предложены конкретные методики формирования христианской морали дошкольников как обобщения возможностей использования исторического опыта исследуемого периода.

Ключевые слова: христианская мораль, доикольники, исторический опыт, пастырская деятельность, конеи XX - начало XXI века. 
BOHDAN SLIVKA. Preschool children' christian ethics formation at the end of the $X X^{\text {th }}-$ the beginning of the XXI $I^{\text {st }}$ centuries: generalization of the opportunities of using the historical experience.

The conceptual approaches to the preschool children' Christian ethics formation in the period of Ukrainian independence have been substantiated. The main determinants of pastoral work with preschool children (anthropology of pastoral care, pastor psychology, pastor pedagogy, preschool education, family education, liturgian chant, etc.) have been determined. The factors influencing the development of preschool children' Christian ethics formation (ideological, philosophical and cultural, scientific and pedagogical, theological, social and economic, educational, organizational and methodological as well as information and technological) have been singled out. The periodization of the development of preschool children' Christian ethics formation in the pastoral pedagogy of the late XX and the beginning of the XXI century has been proposed. The period of 19911999 is characterized by national preschool education formation, setting the concept and basic component of preschool education and introduction of National program titled "Children of Ukraine" considering the revival of religious education against the background of the Soviet Union period past bans. The period of 2001-2009 is defined as the formation of the legislative basis for preschool education, the development of new educational and training programmes for preschool children and the creation of the basic child development programme "I am in the World" with the official introduction of Christian education and aiming at the development of Christian ethics of preschool children. The period of 2010-2013 is characterized by the development of preschool education as an independent branch of Ukrainian pedagogy on the basis of Christianity implementing a new version of the Basic component of preschool education in Ukraine and an updated programme "Child" aiming at the upbringing and education of children from 3 to 7. The period of 2014-2017 is dedicated to the development of Christian ethics, taking into account significant social changes in the context of a new version of "I in the World" programme and the draft Concept of the Development of Education of Ukraine for 2015-2025 years. The main trends in the development of Christian ethics of preschool children by means of pastoral work in Ukraine (such as the involvement of clergy in family education, engagement of pastors in preschool children moral education, formation of educational process on the basis of national values, strengthening of religious orientation of preschool children education and the integration of general and religious educational programmes in the formation of preschool children morality, etc.) have been found out. The specific methods of the preschool children' Christian ethics formation as a generalization of the opportunities of using the historical experience of the studied period have been offered.

Keywords: christian ethics, preschool children, historical experience, pastoral work, the end of the XXth - the beginning of the XXIst centuries.

DOI: https://doi.org/10.31392/NZ-npu-144.2019.22

УДК 378.091:159-051

Степаненко Л. М.

\section{ПРОФЕСІЙНА СПРЯМОВАНІСТЬ У ПІДГОТОВЦІ МАЙБУТНІХ ПСИХОЛОГІВ ДО ВЗАЄМОДІї 3 МАРГІНАЛЬНИМИ СОЦІАЛЬНИМИ ГРУПАМИ}

У статті розглядаються особливості професійної спрямованості у підготовці майбутніх психологів до взаємодії з маргінальними соціальними групами. Задля формування об'єктивних основ якісної професійної підготовки фахівців, було проаналізовано основні полоэнення концепції підготовки майбутніх психологів.

Визначити головні аспекти формування професійної спрямованості у підготовці майбутніх психологів до взаємодї з маргінальними соціальними групами можливо лише при детальному розкритті поняття “професійна спрямованість". Саме тому, нами було проаналізовано поєднання складових у даному понятті. 